\title{
An assessment of emotional Intelligence among girls students studying in professional colleges
}

\author{
Muzamil Jan 1, Asma Hyder 2, Naheed Ruhi 3 \\ 1 Assistant professor, Extension and communication, Institute of Home Science, University of Kashmir \\ 2 Research student, Extension and communication, Institute of Home Science, University of Kashmir \\ 3 Associate Professor, Directorate of Distance Education, University of Kashmir
}

\begin{abstract}
The present study was an attempt to assess the emotional intelligence among girls studying in professional colleges in the Kashmir region. 100 girls students were selected equally from five different colleges, i.e. medical college, engineering college, B.Ed college, Law college and business school through random sampling technique. A scale constructed by Hyde and Pethe (2001) entitled "Emotional Intelligence Scale" was administrated on the sample. The results show that majority of girls studying in professional colleges were in the age group of 21-22 years. It was found that majority of girls have high self-awareness; while empathy is observed at medium level among girls studying in professional colleges. It was also observed that girls have high self motivation; while as their emotional stability is at medium level. Majority of girls have high level of self development. However their value orientation is found at medium level. It was also found that commitment and altruistic behaviour among girls is at medium level. Overall, self esteem among girls studying in professional colleges is observed at high level.
\end{abstract}

\section{Introduction And Related Literature}

Emotional intelligence is the concept which is currently in focus among the general public, practitioners and researchers,. It's being widely believed by the public that emotional and social competence is as important, or even more important, than traditional dimension of intellectual ability and personality (Goleman, 1995 \& 1998). Emotional intelligence is defined as "the composite set of capabilities that enable a person to manage himself/ herself and others" (Goleman, 1995 \& 1998). Importance of Emotional Intelligence is increasingly being recognized and assesses across various professions. Managing emotions in social contexts are clearly important for success in a variety of interpersonal; as well as career-related domains. According to much recent academic work, a good deal or our successes and failures in life are not attributed to our cognitive abilities as measured by tests of IQ, but rather are attributable to our abilities to form and maintain social relationships, portray ourselves positively, and maintain how others perceive us (Richburg, 2002).

Although there are Emotional intelligence (EI) tests that have right and wrong answers, critics still question the validity of these tests. Finally, some researchers contest the validity of emotional intelligence on a basis of it being so closely related to intelligence and personality .Petrides (2000) indicated that females scored higher than males on the social skills factor of measured traits of emotional intelligence. Trinidad et al. (2002) found that adolescents with high emotional intelligence may posses a greater mental ability to read other well and detect unwanted peer pressure. Brackett (2003) studied emotional intelligence and its relation to every day behaviour. 330 college students took an ability test of emotional intelligence, a measure of big 5 personality traits, and provide information on life scales that assessed an array of self-care behavior, leisure persuits, academic activities and interpersonal relations. The results revealed women scored significantly higher in emotional intelligence than men and it was more predictive of life space criteria for men, than for women. It was more predictive of life space criteris for men, than for women. Liau et al. (2003) indicated that emotional literacy served as a moderating factor between the parental monitoring and externalizing problem behaviour. On the contrary, Nezlek (2004) studies emotional intelligence and social interaction on a sample of 118 American college students and 103 German college students respectively. The two studies found positive relationship between the ability to manage emotions and the quality of social interactions. Uma (2005) revealed that among the personal variables, age was not significantly correlated with emotional intelligence. However gender, education and occupation of parents were significantly and positively related with emotional intelligence. Adolescents of joint families were more flexible and adaptable than adolescents of smaller families. Nasir (2009) assessed the relationship of demographic factors with emotional intelligence of university students. It was found that significant correlation existed between intelligence and some of the demographic factors. The model of demographic factors was found significant predictor of emotional intelligence of university students which accounted for 19 per cent variance in emotional intelligence. Similarly Summiya (2009) investigated Emotional Intelligence among male and female on one hundred and sixty subjects, who were categorized in two 
groups (eighty males and eighty females) .Emotional Quotient Inventory (EQ-i) was used to find out the level of emotional intelligence among the subjects. Gender difference on Emotional Quotient Inventory reveals that Males have high emotional intelligence as compare to females $(t=4.522, p<01)$. Olatoye et al. (2010) studied emotional intelligence, creativity and academic achievement of 235 business administration students of polytechniques. The study found that there was a very low negative, no significant relationship between creativity and (CGPI) Cumulative Grade Point Information Scores. There was no significant difference between male and female students academic achievement, creativity and emotional intelligence. Faghirpour et al.(2011) studied the relationship between emotional intelligence and mental health of 503 students cluster sampling method and emotional intelligence questionnaire in the city of Iran and also Goldberg and Hillier mental health questionnaire (GHQ,28) relationship between components of emotional intelligence of students with mental health. It also concluded that people with high emotional intelligence have better mental health. In contrast, Aamina (2012) undertook a study on emotional intelligence and academic achievement of adolescent students on the basis of sex dichotomy on the sample group of 200 students [Male=100,Female $=100]$. The analysis of the data showed that there was no significant difference between male and female students on composite score of their emotional intelligence. It was also found that male and female students do not differ significantly on academic achievement. Gawali (2012) showed a significant relationship between emotional intelligence and positive affectivity, as emotionally intelligent individuals are capable of experiencing more positive emotions and therefore remain cheerful. However, Ruchi (2012) studied the relationship between emotional intelligence, academic motivation and compared the emotional intelligence of students with high and low academic motivation. The findings of the study revealed positive relationship between emotional intelligence and academic motivation. The study also revealed that students with high, moderate and low academic motivation differ from one another on emotional intelligence.

\section{Objectives}

The present study was conducted with following objectives in view:

To assess the emotional intelligence among female students studying in professional colleges in Kashmir.

To study following characteristics among girls studying in professional colleges:

1. Self awareness,

2. Empathy,

3. Self motivation,

4. Emotional stability,

5. Managing relations,

6. Integrity,

7. Self development,

8. Value orientation,

9. Commitment and

10. Altruistic behaviour

\section{Material And Methods}

The study was based on primary data. It was investigated through sample random sampling technique. The information for the study was gathered from girls studying in professional colleges in urban area of district srinagar in Kashmir region of J\&K state in India. For the purpose, 100 sample were selected from five different colleges i.e. medical college, B.ed college, business school, law college, and engineering college. 20 girl students were selected from each college. Equal representation were given to urban and rural girl students i.e. 50 girl students from urban area and 50 from rural area. A readymade scale constructed by Hyde and Pethe (2001) entitled "emotional intelligence scale" was administered on the sample. The data obtained was carefully scrutinized, categorized and coded in order to fulfill the objectives. The data was statistically analysed computing column percentage and quartile (Q1, Q2, Q3). The data was scored under each characteristic of emotional intelligence and quartiles $(\mathrm{Q} 1, \mathrm{Q} 2, \mathrm{Q} 3)$ were calculated. The Q1 depicted the low level of characteristic, Q2 revealed the medium level of characteristic, while as Q3 observed the high level of characteristic. In this way, the levels under each characteristic were studied as:

a) Self awareness: The low level of self awareness scored upto 7 (Q1), the score between 8-11 depicted medium level of self awareness (Q2), while high level of self awareness was observed above the score 12 (Q3).

b) Empathy: Empathy scored upto 12 at low level (Q1), 13-19 at medium level (Q2) and 20 and more at high level (Q3).

c) Self motivation: The score upto $16(\mathrm{Q} 1)$ was considered as low level of self motivation, while the score of 17-21 (Q2) was categorized as medium level of self motivation and the score of 22 and above (Q3) was observed as high level of self motivation. 
d) Emotional stability: Low level of emotional stability scored upto 5 (Q1) where as medium level of emotional stability scored between 6-12 (Q2) and high level of emotional stability scored 13 and above (Q3).

e) Managing relations: This characteristic was observed low (Q1) upto the score of 13. Medium level of characteristic (Q2) scored 14-20, while as high level of characteristic (Q3) scored 21 and above.

f) Integrity: The score upto 8 (Q1) was perceived as low level of integrity, score between 9-11 (Q2) was considered medium level of integrity, while score 12 and above (Q3) was observed as high level of integrity.

g) Self development, value orientation, commitment and altruistic behaviour: These characteristics scored low at the $6(\mathrm{Q} 1)$, medium at the score between 7-8 (Q2) and high at the score of 9 and above (Q3).

h) Self esteem: The overall self esteem was found low at the score of 95(Q1), medium at the score of 96-120 (Q2) and high at the score of 121 and above.

\section{Result And Discussion}

Table 1 shows self awareness and empathy among girls studying in professional colleges. It was found that majority of girl students studying in professional colleges are highly self awared ( 81 per cent). Only 3 per cent girl students are lowly self awared; while as 16 per cent girl students are also self awared at medium level .In the context to empathy, majority of girl students studying in professoional colleges was observed at medium level (52 per cent). Only 5 per cent girl students observed empathy which is at low level; while as 43 per cent girl students have empathy at high level .

Table 2 depicts self motivation and emotional stability among girl students studying in professional colleges. It is found that majority of girl students studying in professional colleges are highly self motivated (63 per cent). Only 5 per cent students are lowly self motivated; while as 32 per cent girl students studying are also self motivated at medium level. In the context to emotional stability, it was found that majority of girl students studying in professional colleges are emotionally stable at medium level (63 per cent). Only 1 per cent girl students are lowly emotionally stable; while as 36 per cent girl students are also emotionally stable at high level.

Table 3 reveals managing relations and integrity among girls studying in professional colleges. It is observed that majority of girl students studying in professional colleges have highly managed relations (77 per cent). Only 2 per cent girl students have lowly managed relations; while as 21 per cent girl students have also managed relations at medium level. In the context to integrity, it was found that majority of girl students studying in professional colleges have high integrity ( 69 per cent). Only 5 per cent girl students have low integrity; while as 26 per cent girl students have also integrity at medium level.

Table 4 shows self development and value orientation among girls studying in professional colleges. It was found that majority of girl students studying in professional colleges are highly self developed (76 per cent). Only 3 per cent girl students are lowly self developed; while as 21 per cent girl students are also self developed at medium level. In the context to value orientation, it was observed that majority of girl students studying in professional colleges are value oriented at medium level (51 per cent). Only 9 per cent girl students are lowly value oriented; while as 40 per cent girl students are also value oriented at high level.

Table 5 shows commitment and altruistic behaviour among girl students studying in professional colleges. It was observed that majority of girl students have commitment at medium level (49 per cent). Only 8 per cent girl students have commitment at low level; while as 43 per cent girl students have also commitment at high level. In the context to altruistic behaviour, it was found that majority of girl students studying in professional have altruistic behaviour at medium level (56 per cent). Only 11 per cent girl students have altruistic behaviour at low level; while as 33 per cent girl students have also altruistic behaviour at high level.

Table 6 depicts overall self esteem of girl students studying in professional colleges. It is found that majority of girl students are highly self esteemed ( 89 per cent). Only 1 per cent girl students are lowly self esteemed; while as 10 per cent girl students are also self esteemed at medium level.

Table 1: Self awareness and empathy among girls studying in professional colleges

\begin{tabular}{|l|l|l|}
\hline Variable & F & $\%$ \\
\hline SELF AWARENESS & & \\
\hline Low & 3 & 3.00 \\
\hline Medium & 16 & 16.00 \\
\hline High & 81 & 81.00 \\
\hline Total & 100 & 100.00 \\
\hline EMPATHY & & \\
\hline Low & 5 & 5.00 \\
\hline Medium & 52 & 52.00 \\
\hline High & 43 & 43.00 \\
\hline Total & 100 & 100.00 \\
\hline
\end{tabular}


Table 2: Self motivation and emotional stability among girls studying in professional colleges

\begin{tabular}{|l|l|l|}
\hline Variable & F & $\%$ \\
\hline SELF MOTIVATION & & \\
\hline Low & 5 & 5.00 \\
\hline Medium & 32 & 32.00 \\
\hline High & 63 & 63.00 \\
\hline Total & 100 & 100.00 \\
\hline EMOTIONAL STABILITY & & \\
\hline Low & 1 & 1.00 \\
\hline Medium & 63 & 63.00 \\
\hline High & 36 & 36.00 \\
\hline Total & 100 & 100.00 \\
\hline
\end{tabular}

Table 3: managing relations and integrity among girls studying in professional colleges

\begin{tabular}{|l|l|l|}
\hline Variable & F & $\%$ \\
\hline MANAGING RELATIONS & & \\
\hline Low & 2 & 2.00 \\
\hline Medium & 21 & 21.00 \\
\hline High & 77 & 77.00 \\
\hline Total & 100 & 100.00 \\
\hline INTEGRITY & & \\
\hline Low & 5 & 5.00 \\
\hline Medium & 26 & $\mathbf{2 6 . 0 0}$ \\
\hline High & 69 & 69.00 \\
\hline Total & 100 & 100.00 \\
\hline
\end{tabular}

Table 4: self development and value orientation among girls studying in professional colleges

\begin{tabular}{|l|l|l|}
\hline Variable & F & $\%$ \\
\hline SELF DEVELOPMENT & & \\
\hline Low & 3 & $\mathbf{3 . 0 0}$ \\
\hline Medium & 21 & $\mathbf{2 1 . 0 0}$ \\
\hline High & $\mathbf{7 6}$ & $\mathbf{7 6 . 0 0}$ \\
\hline Total & $\mathbf{1 0 0}$ & $\mathbf{1 0 0 . 0 0}$ \\
\hline VALUE ORIENTATION & & \\
\hline Low & 9 & $\mathbf{9 . 0 0}$ \\
\hline Medium & $\mathbf{5 1}$ & $\mathbf{5 1 . 0 0}$ \\
\hline High & 40 & $\mathbf{4 0 . 0 0}$ \\
\hline Total & 100 & $\mathbf{1 0 0 . 0 0}$ \\
\hline
\end{tabular}

Table 5: commitment and altruistic behaviour among girls studying in professional colleges

\begin{tabular}{|l|l|l|}
\hline Variable & F & $\%$ \\
\hline COMMITMENT & & \\
\hline Low & 8 & 8.00 \\
\hline Medium & 49 & 49.00 \\
\hline High & 43 & 43.00 \\
\hline Total & 100 & 100.00 \\
\hline ALTRUISTIC BEHAVIOUR & & \\
\hline Low & 11 & 11.00 \\
\hline Medium & 56 & 56.00 \\
\hline High & 33 & 33.00 \\
\hline Total & 100 & 100.00 \\
\hline & & \\
\hline
\end{tabular}

Table 6: self esteem among girls studying in professional colleges

\begin{tabular}{|l|l|l|}
\hline Variable & F & $\%$ \\
\hline SELF ESTEEM & & \\
\hline Low & 1 & 1.00 \\
\hline Medium & 10 & 10.00 \\
\hline High & 89 & 89.00 \\
\hline Total & 100 & 100.00 \\
\hline
\end{tabular}

IV. Conclusion:

Emotional intelligence is a set of abilities that includes accurately perceiving emotions, expressing emotions appropriately understanding the causes and consequences of emotions and managing one's own and others feelings to facilitate thinking and social interaction. It is the ability to monitor one's own and others feelings and emotions, to discriminate among them, and to use this information to guide one's thinking and actions. Thus, emotional intelligence is an umbrella term that captures a broad collection of interpersonal and intrapersonal skills. The present study shows that girl students have high self awareness, self motivation, 
integrity, self development and self esteem which have a positive impact on them. Empathy, emotional stability, value orientation, commitment and altruistic behaviour are observed at medium level among girls studying in professional colleges.

\section{References}

[1]. Ahmad, S., Bangash, H., and Khan, S.A.(2009). Emotional intelligence and gender differences. Journal of Sarhad J. Agric. Vol.(25). No.(1).127-130.

[2]. Bracket, M.A., Mayer, J.D., and Warner, R.M. (2003). Emotional Intelligence and its relation to everyday behaviour. Journal of Personality and Individual Differences. Vol.(36). 1387-1402.

[3]. Dubey, R.( 2012). Emotional intelligence and academic motivation among adolescents: A relationship study. International Journal of Multidisciplinary Research. Vol.(2). No.(3). 142-147

[4]. Faghirpour, M., and Amoopour, M. (2011). The relationship between emotional intelligence and mental health of students. Journal of Basic And Applied Scientific Research. Vol.(1). No.(12). 70-89.

[5]. Gawali, K.C.(20012). The relationship between emotional intelligence and positive affectivity among college teachers. Journal of Intelligence. Vol.(1)Issue (8). 996.

[6]. Goleman, D. (1995). Emotional intelligence. New York: Bantam Books.

[7]. Goleman, D. (1998). Working with emotional intelligence. New York: Bantam Books.

[8]. Liau, A.K., Liau, A.W., Teoh, G.B., and Liau, M.T. (2003). The case for Emotional Literacy: The influence of emotional intelligence on problem behaviours in Malaysian secondary school students. Journal of Moral Education .Vol.(32). Issue I.

[9]. Nasir, M., and Iqbal, S.(2009). Relationship of demographic factors with emotional intelligence of university students. Journal of New Horizons in Ssience and Technology.VOL.(1).Issue(16). 17-21.

[10]. Nezlek, J.B., Lopes, P.N., Brackett, M.A., Schutz, A., Sellin, I., and Salovev, P.(2004). Emotional intelligence and social interaction. Journal of Personality socspsychol Bull. Vol.(30). No.(8). 1018-1034

[11]. Olatoye, R.A., Akintunde, S.O., and Yokasai, M.I.(2010). Emotional Intelligence, creativity and academic achievement of business administration students. Electronic Jpurnal of Educational Psychology. Vol.(2). 763-786.

[12]. Parveen, A., Malik, M.A., Aziz, R.(2012). Emotional intelligence and academic achievement of male and female adlolescent students of diostrict Budgam. Journal of Education and Practice. Vol.(3). No.(15). 184-186.

[13]. Petrides, K.V., and Furnham, A. (2000). Gender differences in measured and self estimated trait emotional intelligence. Journal of Psychology. Vol.(42). 5-6.

[14]. Richburg, M., Fletcher, T.(2002).Emotional intelligence: Directing a child's emotional education. Journal of Child Study. Vol.(32). 31-38.

[15]. Trinided, D.R., and Johnson, C.A. (2002). The association between emotional intelligence and early adolescent tobacco and alcohol use. Journal of Personality and Individual Differences. Vol.(32). Issue I. 95-105.

[16]. Uma, L., and Uma, D. (2005). Relationship between the dimensions of the emotional intelligence of adolescents and selected, social variables. Journal of Psychological review.Vol.(64). Issue I. 11-20. 